Рибидайло А. А., к.т.н., с.н.с.;

Турейчук А. М., к.т.н.;

Прокопенко О. С.

Центр воєнно-стратегічних досліджень Національного університету оборони України імені Івана Черняховського, Київ

\title{
Аналіз досвіду провідних країн світу щодо формування та використання кадрового резерву у збройних силах
}

Резюме. В статті узагальнено досвід армій провідних країн світу щодо створення кадрового резерву та здійснено аналіз світових тенденцій стосовно автоматизації процесів кадрового менеджменту.

Ключові слова: кадровий резерв, комплектування збройних сил, принципи формування збройних сил, автоматизовані системи управління персоналом.

Постановка проблеми. Кожна держава зобов'язана вибудовувати багаторівневу систему безпеки, яка має політичну, економічну, дипломатичну i оборонну складові. Хоча гармати і не $\epsilon$ "останнім аргументом", але іноді тільки наявність ефективних збройних сил, дозволяє добитися результатів дипломатичними методами.

У світі існують різні підходи до формування збройних сил, але найбільш ефективним, 3 точки зору боєздатності, швидкого розгортання і чисельності, були, $є$ i залишаються армії, що структурно складаються з регулярних військ і резерву [1].

Збройні сили будь-якої країни, а України особливо, унаслідок наявності агресивного сусіда, що не лише має територіальні домагання, але й втілює агресію в життя, повинні виконувати завдання:

- підтримка кваліфікованої кадрової армії для вирішення поточних завдань оборони;

- формування кваліфікованого резерву для поповнення кадрової армії $\mathrm{i}$ швидкого збільшення іiї складу в періоди криз;

$$
\text { - створення }
$$

мобілізаційної

інфраструктури на випадок конфліктів.

Контрактна армія України в змозі вирішити тільки перше завдання. Два інші завдання вирішуються лише за рахунок резервістів, які пройшли службу і підготовку за роки існування військової повинності. Таким чином, 3С України вимагають реорганізації і не лише з точки зору складу озброєння і якості військової підготовки регулярних військ, але i 3 точки зору комплектування особовим складом i підготовки резерву.
Формування дієвого Резерву кандидатів для просування по службі та забезпечення його ефективного використання кадровими органами Збройних Сил України вимагає проведення певних досліджень, які можна подати у вигляді структурно-логічної схеми на рис. 1 :

Дійсна стаття присвячена висвітленню результатів досліджень за першим напрямком, a саме, аналізу передового досвіду щодо формування та використання кадрового резерву

Аналіз останніх досліджень i публікацій. У відкритих джерелах достатня кількість робіт, наприклад [2], присвячених вирішенню питань підвищення якості військової підготовки регулярних військ i резерву, а також способам комплектування збройних сил особовим складом в періоди криз та загострення політичної обстановки в регіоні. Розглядаються принципи формування збройних сил: професійно добровільний; міліційний i міліційно-кадровий; кадрово-призовний. Крім того розглянуті територіальний i екстериторіальний способи формування збройних сил.

У джерелах [3-5] висвітлені особливості формування дієвого Резерву у провідних країнах світу.

Метою статті є узагальнення досвіду армій провідних країн світу щодо створення кадрового резерву та аналіз світових тенденцій стосовно автоматизації процесів кадрового менеджменту.

Виклад основного матеріалу. Результатом підготовки кадрового резерву $\epsilon$ формування певного складу громадян, що пройшли підготовчий відбір (оцінку) і мають необхідний потенціал для виконання прямих обов'язків на необхідній посаді у встановлені терміни. 
НАПРЯМКИ ДОСЛІДЖЕНЬ

Аналіз передового досвіду щодо формування та використання кадрового резерву збройних сил

Аналіз існуючого порядку формування Резерву кандидатів для просування по службі у Збройних Силах України

Аналіз нормативно-правової бази щодо порядку формування та використання Резерву кандидатів у Збройних Силах України

\section{Потреби органів кадрового менеджменту ЗС України}

\section{ШЛЯХИ УДОСКОНАЛЕННЯ (РОЗРОБКА ПРОПОЗИЦЙ)}

Розробка Проекту змін до нормативно-правових документів, які регламентують порядок формування та використання Резерву кандидатів у Збройних Силах України
Розробка Проекту методичних рекомендацій з порядку визначення рейтингу військовослужбовців Збройних Силах України
Удосконалення ведення бази даних Резерву кандидатів. Розробка експериментального макету АРМ та методики його використання.

\section{Стратегія впровадження результатів}

Рис. 1. Структурно-логічна схема досліджень

Іншими словами, кадрові резерви - це громадяни держави, що плануються для призначення на необхідні посади. Такий запас кандидатур має умовну структуру. Кадровий резерв (професійний запас) може бути як внутрішнім, так і зовнішнім. Що стосується внутрішнього резерву, то він складається 3 діючих військовослужбовців і розділяється на оперативний і перспективний.

Оперативний резерв - це діючі військовослужбовці, які здатні замінити вищестоящих начальників і готові без якихнебудь додаткових повчальних заходів обійняти певні посади.
Перспективний резерв - це діючі військовослужбовці з великим потенціалом, але що мають необхідність в додатковому навчанні.

Формування зовнішнього резерву здійснюється зі складу військовозобов'язаних громадян держави. У кожній державі до виконання військового обов'язку притягуються певні категорії населення.

Наведену класифікацію можна представити у вигляді схеми, представленої на рис. 2.

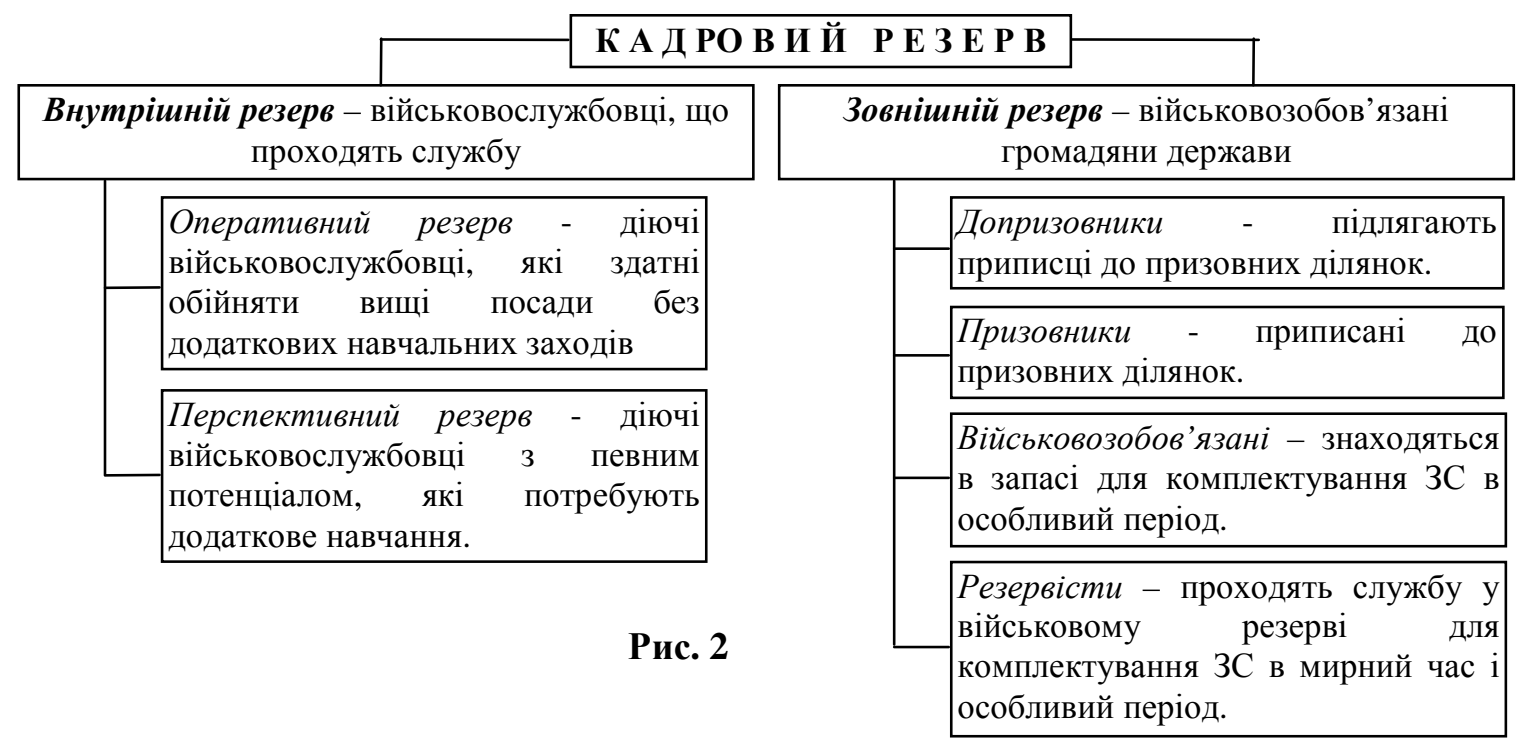

Аналіз досвіду провідних країн світу щодо формування та використання кадрового резерву, відповідно до класифікації, яка наведена на рис. 2, зручно проводити окремо для категорій зовнішнього i внутрішнього кадрових резервів. Крім того, доцільно

вивчити досвід щодо автоматизації процесів обліку кадрового резерву та відслідкування кар'єрного росту діючих військовослужбовців.

Професійні армії. Нині повністю професійні армії мають понад п'ятдесят держав, включаючи такі досить великі країни, 
як Японія, Індія, Пакистан, Канада, Австралія, Нігерія і Філіппіни. При цьому не усі вони захищені від потенційних супротивників океанами або територією союзників. Японію відділяє від Російської Федерації смужка води шириною в декілька десятків кілометрів. Індія i Пакистан, що стабільно ворогують між собою мають декілька тисяч кілометрів спільного сухопутного кордону.

Найбільш потужною i численною професійною армією володіють СШ山А. Комплектування збройних сил здійснюється на добровільній основі. Усі кандидати піддаються тестуванню з метою виявлення їх загальноосвітнього рівня, схильностей i здібностей, можливості і доцільності використання по обраній ними спеціальності. За результатами тестування кандидати розподіляються по відповідних військовооблікових спеціальностях.

Після прийняття присяги новобранці прямують в учбові центри видів збройних сил для проходження початкової підготовки i підготовки за фахом.

Національна гвардія займає незвичайне місце в системі збройних сил США. 3 одного боку, це війська штатів (iі формування створюються в усіх п'ятдесяти штатах), які підпорядковані губернаторам штатів i використовуються ними для підтримки громадського порядку, ліквідації наслідків стихійних лих i рішення інших завдань. 3 іншого боку, національна гвардія бойовий резерв збройних сил США, що об'єднує у своєму складі значну частину військової потужності сухопутних військ i ВПС США (військово-морських сил у складі національної гвардії немає). Відповідно до концепції "єдиних сил" вважається необхідним доведення боєздатності національної гвардії до рівня регулярних військ відносно укомплектованості особовим складом, оснащення зброєю і технікою, якості занять 3 бойової підготовки.

Резерв американських збройних сил, як i регулярні війська, комплектується на добровільній основі. Усі резервісти знаходяться на грошовому утриманні. Підставою виплати служить контракт, що укладається резервістом 3 міністерством оборони. Рядовий i сержантський склад резерву поповнюється за рахунок військовослужбовців регулярних військ, достроково звільнених 3 дійсної служби i зобов'язаних за умовами контракту дослужити термін служби в резерві, колишніх військовослужбовців, що виявили бажання служити в резерві, а також осіб, що раніше не проходили військову службу і завербувалися за контрактом. Офіцерський склад резерву комплектується з колишніх кадрових офіцерів, випускників курсів загальновійськової підготовки офіцерів резерву при цивільних ВН3, а також з випускників офіцерських шкіл, які набирають своїх слухачів 3 резервістів рядового і сержантського складу.

На службу в армію Японії приймаються особи чоловічої і жіночої статі у віці від 18 до 25 років. Термін служби по первинному контракту в сухопутних військах два роки, у ВПС i BMC, a також для технічних спеціальностей сухопутних військ - три роки. Після закінчення первинного контракту термін його дії може подовжуватися.

На відміну від США, що практикують заклик в резерв добровольців, що раніше не проходили військову службу. Японія комплектує резерв своєї армії тільки за рахунок осіб, що пройшли службу в регулярних військах. Служба в резерві оплачується у вигляді щомісячних грошових виплат резервістові. Із загального числа військовослужбовців, що щорічно звільняються, приблизно половина зараховуються в резерв, інші військову перепідготовку не проходять. Перепідготовка резервістів здійснюється в період учбових зборів. Законом про "сили самооборони" передбачається можливість проведення одногодвох зборів на рік, при цьому загальна їх тривалість не перевищує 20 діб. На практиці збори обмежувалися п'ятьма добами на рік. Резервісти, що звільнилися зі збройних сил не більше року тому, впродовж першого року перебування в резерві проходять одноденні збори. Загальна чисельність резерву японських “сил самооборони" менше 50 тис. чол., у тому числі в сухопутних військах - 46 тис. чол., ВМС - 1,1 тис. чол., ВПС - 0,8 тис. чол.

Таким чином, чисельність, невеликого i молодого по віковому цензу, резерву японської армії не перевищує $20 \%$ чисельності регулярних військ при населенні країни близько 130 млн. чол.

Міліційні і кадрово-міліційні армії $\epsilon$ прямою протилежністю чисто професійним арміям.

Для міліиійних армій характерна відсутність кадрових військових формувань i практично повне заміщення командних посад офіцерами, для яких військова служба не $\epsilon$ основною професією. У чистому вигляді міліційна армія існує тільки в Швейцарії, де військовозобов'язаним вважається усе чоловіче 
населення у віці від 20 до 50 років, придатне за станом здоров'я до несення військової служби. У армію призивається 91-92\% чоловічого населення - більше, ніж в будь-якій іншій країні (можливо, окрім Ізраїлю).

Швейцарія, при населенні близько 7 млн. чоловік здатна відмобілізувати і розмістити на оборонних рубежах впродовж 48 годин 650 тис. озброєних і навчених бійців. Стрілецьку зброю, боєприпаси і обмундирування резервісти зберігають удома.

Кадровий склад швейцарської армії налічує всього біля 3500 чол. До нього відносяться тільки офіцери і унтер-офіцери інструкторського складу учбових центрів. Що стосується частин і з'єднань швейцарської армії, то кадровими військовослужбовцями $є$ тільки командири дивізій i вище. Решту складають військовозобов'язані. Після проходження у віці 20 років рекрутської школи тривалістю $119 \quad$ діб військовозобов'язані зараховуються в резерв першої черги. У його складі вони знаходяться до досягнення ними 32 років. За цей період вони проходять 8 зборів бойової підготовки у складі частин і підрозділів, що розгортаються в учбових цілях за штатами військового часу. Тривалість кожного збору 20 діб (всього 160 діб). У віці 43-50 років військовозобов'язаний перебуває в резерві третьої черги. Впродовж цього періоду його бойова підготовка обмежується двома зборами (13 діб). Таким чином, рядовий склад призивається на військову службу загальною тривалістю 330 діб. Унтер-офіцери служать 511 доби, офіцери - 906 діб.

Головною особливістю кадровоміліційних армій є утримання в мирний час невеликих кадрових збройних сил 3 нетривалими термінами обов'язкової військової служби, у поєднанні з підтримкою у високому ступені мобілізаційної готовності численних навчених резервів. Крім того, в країнах 3 кадрово-міліційними арміями, окрім регулярної армії і іiі резервів, зазвичай створюються в якості самостійного компонента збройних сил і чисто міліційні формування, що комплектуються, як правило, на добровільній основі.

Типовий приклад кадрово-міліційної армії дає Данія. Регулярні датські збройні сили складають близько 31 тис. чоловік, у тому числі 9,2 тис. призовників. Інший контингент складається 3 кадрових військовослужбовців, у тому числі 3 добровольців рядового i унтер-офіцерського складу, що набирають за контрактом.
Вирішальна роль відводиться навченим резервам. У разі мобілізації чисельність датських збройних сил, в порівнянні з періодом мирного часу, зростає більш ніж вчетверо. Основне призначення регулярних військ підготовка резервів i забезпечення мобілізаційного розгортання. В учбовомобілізаційних полках проводиться навчання тільки рядового складу. Підготовка молодших командирів (унтер-офіцерів) здійснюється в школах i учбових центрах родів військ. Навчанням офіцерів займаються офіцерська школа в Копенгагені, школи офіцерів резерву і заочна офіцерська школа.

Чисто міліційним компонентом датських збройних сил є “хемверн” озброєна добровільна організація, побудована за територіальним принципом. У неї зараховуються добровольці від 16 до 50 років. В основному це колишні військовослужбовці, вибулі з резерву за віком або стану здоров'я, а також особи, звільнені 3 якої-небудь причини від термінової військової служби. Командний склад "хемверна" комплектується за рахунок офіцеріввідставників датської армії, а також за рахунок випускників власної командної школи. Особовий склад "хемверна" навчається, як правило, у вільний від роботи час. Таким чином, у разі мобілізації Данія (населення 5,1 млн. чол.) здатна в стислі терміни виставити, включаючи регулярні війська, резерви i “хемверн” в розмірі близько 200 тис. навчених i озброєних бійців.

Ще більшу кількість військ по відношенню до власного населення можуть виставити інші країни, що дотримуються кадрово-міліційної системи комплектування збройних сил. Так, Норвегія (населення 4,2 млн. чол.) при чисельності регулярної армії 34 тис. здатна у разі потреби відмобілізувати впродовж 24-72 годин армію в 400 тис. чол. (у тому числі 285 тис. резервістів регулярної армії і 85 тис. бійців міліційної місцевої гвардії), не рахуючи 60 тис. резервістів другої черги. Швеція (населення 6,4 млн. чол., регулярна армія 64,5 тис. чол.) здатна впродовж 2-3 діб поставити під рушницю 850 тис. чол., включаючи 125 тис. добровольців територіальної гвардії. Останні здатні зайняти відведені їм по мобілізаційному плану позиції впродовж однієї години.

Слід зазначити, що число країн 3 кадрово-міліційними арміями продовжує зростати. Зокрема, в середині $70-x$ років на кадрово-міліційну систему комплектування перейшла Австрія. Не вважають територіально-міліційний принцип застарілим i 
країни 3 професійними арміями. Вони успішно використовують його для підготовки резервів (наприклад, національна гвардія збройних сил США).

Кадрово-призовні армії займають проміжне положення між професійними i кадрово-міліційними. Їх об'єднуючою ознакою $\epsilon$ використання принципу військового обов'язку 3 порівняно тривалим (більше року) терміном служби призовників. На відміну від професійних, кадрово-закличні армії мають більше підготовлених резервів і велику загальну чисельність по відношенню до числа жителів країни. В порівнянні 3 кадрово-міліційними арміями вони містять в мирний час чисельні регулярні війська, але мають менше резервів. Як правило, підготовка ï резервістів відрізняється від професійних i кадрово-міліційних армій меншою інтенсивністю і регулярністю.

Кадрово-прзовні армії мають більше половини країн НАТО, у тому числі Німеччина, Франція, Італія, Іспанія, Туреччина, а також багато інших країн світу, наприклад, Російська Федерація, Бразилія, Аргентина, Індонезія, Південна Корея, Сирія. Терміни обов'язкової служби в таких арміях від 12 місяців (Італія, Іспанія) до 30-36 місяців (Сгипет, Південна Корея) і до трьох-чотирьох років (Китай).

Типовою кадрово-призовною армією $\epsilon$ збройні сили Німеччини (бундесвер). Усі громадяни Німеччини чоловічої статі у віці від 18 до 28 років повинні проходити термінову військову службу. Ї̈ тривалість 15 місяців. Більше половини $(55 \%$ загальної чисельності регулярної армії) комплектується на добровільній основі. Усі добровольці діляться на дві категорії: військовослужбовці за контрактом (контракти полягають на термін від 2 до 15 років) і кадрові (службовці до встановленого законом граничного віку). Після закінчення терміну контракту військовослужбовці, що підписали його, отримують вихідну допомогу. Кадрові військові після досягнення встановленого віку мають право на отримання пенсії.

Військовозобов'язані, такі, що відслужили дійсну службу, зараховуються в резерв. Усі резервісти діляться на декілька категорій готовності, відповідно до яких вони можуть бути знову покликані у збройні сили. Військовослужбовці, що завершили термінову службу або службу за контрактом зараховуються до резерву постійної готовності, в якому вони залишаються приписаними до своїх частин впродовж 12 місяців після демобілізації. Впродовж цього часу вони можуть бути покликані на службу із запасу наказом міністра оборони, тобто без оголошення в країні мобілізації. Після закінчення зазначеного терміну резервісти переводяться до складу резерву першої черги, призначеного для доукомплектування бундесверу до штатів військового часу. Інші резервісти зараховуються в резерв другої черги i, так званий, загальний резерв. Дві останні категорії резерву призначені для заповнення можливих втрат військ в ході бойових дій і для можливого формування додаткових частин i з'єднань. Навчання резервістів здійснюється шляхом проведення учбових зборів, в ході мобілізаційних навчань, а також під час мобілізаційних зборів по тривозі. Тривалість зборів - 2-4 тижні, мобілізаційних навчань - до 12 діб, мобілізаційних зборів по тривозі - до 3 діб.

Російська Федерація. У 2013 році в засобах масової інформації, зокрема [6], повідомлялося, що статус резервістів ВС Росії не прописаний $\mathrm{i}$ це не дозволяє вести нормальне мобілізаційне планування. Одним 3 етапів реформи, що почалася, стало створення в кожному окрузі органів військового управління, що відповідають за підготовку військового резерву. При цьому одна 3 найскладніших проблем Збройних Сил Росії, на думку аналітиків, - підтримка укомплектованості військ при веденні бойових дій.

У Збройних силах РФ існують такі поняття як поточний і тимчасовий некомплект (ПНК і ТНК). Поточний - це наявність посад, які не заповнені військовослужбовцями (вакантні), а тимчасовий - коли військовослужбовець, що стоїть на посаді, убув у відрядження, відпустку, на лікування i не виконує свої службові обов' язки тривалий час, але при цьому числиться на посаді і повинен повернутися до виконання своїх службових обов'язків.

У 2013 році було проведено декілька експериментальних навчань по розгортанню баз зберігання і ремонту озброєння і військової техніки (БЗРОВТ), що залишилися, центральних баз резерву техніки (ЦБРТ) i навчань по доукомплектуванню особовим складом частин постійної бойової готовності в умовах як мирного часу, так і бойових дій, використовуючи різні принципи приписки особового складу i укомплектовування технікою. Результатом стало рішення створити командування резерву, що отримало під свій контроль не лише військові комісаріати, але i 
БЗРОВТ і ЦБРТ. В окружних учбових центрах почалися експерименти по підготовці, так званих, резервістів за контрактом. У їх складі з'явилися знову створені на основі Плану оборони РФ батальйони територіальної оборони, які виконували завдання по охороні і обороні важливих об' єктів інфраструктури 3С, а також по наданню допомоги у боротьбі 3 іррегулярними формуваннями.

На відміну від збройних сил США в російській системі не планується розділення на резервістів i національних гвардійців, командування резерву саме вирішуватиме, закріплюється резервіст за частиною постійної готовності або за однією з баз зберігання i ремонту, що розгортаються у військовий час у військовій частині. Формування цих органів військового управління вже завершене і якраз підсумковою перевіркою їх готовності стали навчання "Восток-2014".

Необхідно враховувати, що традиційно система мобілізаційного розгортання Збройних Сил Росії залишається під грифом "Цілком таємно" і про конкретні результати перевірки доки нічого невідомо. Досі немає законодавчого рішення про статус резервістів за контрактом. При цьому системи резервних компонентів в іноземних арміях світу в основі мають чітко прописаний статус резервіста, його права i обов'язки перед державою, на основі яких вибудовуються інші компоненти системи. Російські військові аналітики припускають, що нинішній міністр оборони доведе до кінця реформування системи мобілізаційного резерву i Російська армія отримає надійну дворівневу систему резервних компонентів.

Довідка. У арміях західних країн проблема вже давно розв'язана створенням дворівневої системи резервних компонентів. Перший рівень заповнення некомплекту безпосередньо у військах, a другий - розгортання додаткових військових частин при необхідності.

17 липня 2016 року президент В. Путін підписав Указ № 370 "Про створення мобілізаційного людського резерву Збройних Сил Російської Федерації" [3]. Тим самим Росія зробила ще один крок до створення повністю професійної армії. Нині вже біля $50 \%$ чисельності складають бійці, що проходять службу за контрактом - 300 тисяч рядових і сержантів і 200 тисяч офіцерів. Але це стосується “кадрової” армії, розгорнутої i готової приступити до бойових дій у будьякий момент.

Офіційна чисельність Російської армії на 2016 рік офіційно становить близько мільйона осіб [7]. До останнього часу у багатьох частинах спостерігався некомплект особового складу до 30\%. На початку 2016 року було оголошено, що вперше число контрактників перевершила кількість військовослужбовців за призовом: в даний час в Російській армії служать 300 тис. контрактників і 276 тис. строковиків. Мобілізаційна система країни в даний час розбалансована, проте активний резерв залишається досить значним i становить близько 2,5 млн. осіб.

Туреччина. Турецька армія $\epsilon$ другою за чисельністю в НАТО - більшою володіють лише США. Бойовий склад армії Туреччини налічуе понад півмільйона військовослужбовців, ще 400 тис. перебувають в найближчому резерві. На військову службу в Туреччині призивають 320 років, термін служби може тривати до 15 місяців (призовники 3 вищою освітою служать удвічі менше). Втім, як свідчать експерти, все-таки більшість рекрутів - це вихідці 3 сіл, які не мають майже ніякого освіти. В результаті, при зразковій дисципліні в частинах, турецькі солдати практично нездатні ефективно використовувати сучасну військову техніку (бракує знань). При цьому: ядро турецької армії становлять якісний офіцерський корпус $\mathrm{i}$ підготовлені контрактники. Більшість фахівців служить в авіації, частинах спеціального призначення, морській піхоті. Також для відмобілізування у воєнний час може бути використаний навчений військовій справі резерв чисельністю до 900 тис. чоловік.

Слід зазначити, що у збройних силах іноземних держав широко використовуються автоматизовані системи управління персоналом. Серед великого розмаїття автоматизованих систем закордонної розробки, в яких інтегровані функції, щодо обліку та управління персоналом, найбільш цікавими, 3 точки зору інформатизації воєнного відомства, $\epsilon$ системи, які дозволяють виконувати широкий спектр завдань кадрового менеджменту, мають сучасні технологічні рішення щодо розроблених платформ, несуть в собі інтегративні властивості з базами даних інших систем, мають необхідний інструментарій для побудови звітних форм та потокового завантаження зовнішніх даних.

Автоматизовані системи 3 вище означеними властивостями, як правило, $є$ ERPсистемами (Enterprise Resource Planning), побудовані за модульним принципом й мають у своєму складі модуль НСM (Human Capital Management - управління людським капіталом), що реалізує не лише 
автоматизоване управління кадрами, а й об‘єднує управління талантами, розвиток персоналу, набір (підбір) персоналу, нарахування заробітної плати та багато інших рішень. Найбільш відомими у світі, та поширеними за кількістю впроваджень на підприємствах, міжнародних корпораціях та організаціях ERP-систем 3 HCM-модулем $\epsilon$ : SAP R/3, Oracle ma Microsoft Dynamics $A X$ (Axapta).

Безумовно, західні розроблювачі вклали в створення даних НСМ-модулів величезні людські й матеріальні ресурси, а також накопичили досвід їх впровадження на сотнях i тисячах закордонних підприємств. У той же час, існують певні обмеження для поширення цих модулів на українських підприємствах (не беручи до уваги такі фактори, коли власниками підприємства є західні інвестори, a впроваджувана система прийнята як корпоративний стандарт). Основними із цих обмежень $\epsilon$ :

висока ціна впровадження й підтримки;

функціональна надмірність - дані НСМмодулі включають незатребувані поки у вітчизняних установах функції;

недостатня швидкість адаптації до динамічно мінливого законодавства;

у деяких випадках, недостатня повнота локалізації інтерфейсів.

Сучасні IAC, які створено на підприємствах пострадянського простору вирішують багато задач кадрового менеджменту:

\section{- “1С:Зарплата та управління}

персоналом 8.0” - програма масового призначення, що дозволяє в комплексі автоматизувати задачі установи, пов'язані 3 розрахунками заробітної плати персоналу i реалізацією кадрової політики;

- система "Парус-Заробітна плата" дозволяє: реєструвати в системі анкети співробітників, створювати штатний розпис по співробітниках 3 можливістю створення підлеглих підрозділів, вносити до системи стандартні кадрові накази 3 їхнім автоматичним відпрацьовуванням тощо.

Інформаційна система в роботі 3 персоналом “Флагман” - повнофункціональний програмний продукт класу ERP, призначений для створення інформаційних систем управління установами;

- IAC-“Кадровик" - IAC управління персоналом, дозволяє оптимізувати процеси управління людським ресурсом у великих, середніх установах що динамічно розвиваються, здійснюється опис організаційної структури установи, а також ведення всієї облікової роботи по персоналу за допомогою автоматизованого виконання операцій приймання, переміщення, звільнення співробітників, а також підготовки та обліку наказів, формування різноманітних списків i звітних документів, розрахунку заробітної плати тощо.

- IAC “Галактика" орієнтована на установи 3 повномасштабним кадровим обліком, що включають ведення особистої картки, військово-облікової інформації тощо, а також на організації 3 нестандартними структурами, що містять позаштатних працівників, сумісників, географічно розгалужену мережу представництв.

Вибираючи інформаційну систему управління персоналом, необхідно звернути увагу на пропрацьованість областей, необхідних для вирішення потреб конкретної установи. Розроблювачі вітчизняних систем автоматизації та впроваджувальні установи, що спеціалізуються на західних програмних продуктах, сходяться в тому, що вибір системи автоматизації залежить від завдань, які вона покликана вирішувати. Слід зазначити, що універсальних рішень, які повноцінно задовольняють потреби установ різних галузей, розмірів і моделей управління, не існує.

\section{Висновки.}

1. В арміях іноземних держав в наявності різні способи проходження військової служби: на постійній основі в кадрах; за контрактом і за призовом. Переважна більшість офіцерів армій розглянутих держав проходять військову службу на постійній основі (в кадрах). Всіляко заохочується тривалий шлях військової служби, переукладання контрактів, що дозволяє підвищити професіоналізм військовослужбовців, скоротити витрати на їх підготовку.

2. В сучасних іноземних арміях широко використовується система атестування військовослужбовців. Атестування проводиться щорічно (США). Постійні звання присвоюються тільки на підставі позитивної атестації (США, Німеччина та ін.). Широко використовується атестування при призначенні на посаду. При цьому враховується думка вищого командування, товаришів по службі, результати тестування, думка громадськості (в тому числі і в пресі) - США.

3. Закордоні системи управління персоналом мають у своєму составі Human Resources (HR) модулі - SAP R/3 i Oracle Applications. Обидві системи мають класичні функції щодо управління персоналом: 
табельний облік в установі; процедуру наймання персоналу; врахування професійноважливих властивостей $\mathrm{i}$ ділових якостей співробітників підприємства; врахування потреб сучасного навчання персоналу; планування розвитку кар'єри співробітників установи та розробку компенсаційної політики для персоналу та ін.

Сучасні IAC, створені на пострадянському просторі вирішують задачі управління персоналом установи 3 врахуванням світових тенденцій та побудовані по модульному принципу. Але при розробці не передбачено іх інтеграцію до автоматизованих систем управління процесами діяльності установи вищого рівня.

У подальшому для поліпшення ефективності кадрових рішень дослідження доцільно присвятити аналізу ефективності використання Резерву кандидатів для просування по службі у видах Збройних Сил України.

\section{СПИСОК ВИКОРИСТАНОЇ ЛІТЕРАТУРИ}

1. Как защитить Украину и кто такая национальная гвардия? режим доступу: http://blog.liga.net/user/snosach/article/14039.aspx

2. В. Шлыков. Принципы формирования армии: мировой опыт. Электронный ресурс. Режим доступа:

shlykov_principy_formirovaniya_armii_mirovoi_opyt .pdf

3. А.Е. Калинин Порядок прохождения военной службы в зарубежных государствах (США, Великобритания, Франция, ФРГ и др.). Режим доступа: http://zodorov.ru.

4. В. И. Андреев Сравнительный анализ подготовки офицеров в армиях зарубежных государств и Республики Беларусь. Наука и военная безопасность № 1/2007, стр. 58-63.

5. Матвеенко А. А. По зарубежным странам и армиям / Зарубежное военное обозрение. - 2000. № 1. - С. 26 - 39 .

6. Резерв армии пора вернуть в строй. армейский вестник. режим доступа: http://armynews.ru/2014/10/rezerv-armii-pora-vernut-v-stroj.

7. Вооружены и очень опасны. Режим доступу:https://versia.ru/armiya-turcii-ivooruzhyonnye-sily-rf-sravnivaem-vozmozhnosti.

Стаття надійшла до редакції 26.06.2017

Рыбыдайло А. А., к.т.н., с.н.с.;

Турейчук А. М., к.т.н.;

Прокопенко А. C.

Центр военно-стратегических исследований Национального университета обороны Украины имени Ивана Черняховского, Киев

Анализ опыта ведущих стран мира относительно формирования и использования кадрового резерва в вооруженных силах

Резюме. В статье обобщен опыт армий ведущих стран мира по созданию кадрового резерва и осуществлен анализ мировых тенденций относительно автоматизации процессов кадрового менеджмента.

Ключевые слова: кадровый резерв, комплектование вооруженных сил, принципы формирования вооруженных сил, автоматизированные системы управления персоналом.

A. Rybydajlo, Ph. D, senior researcher;

A. Tureychuk, Ph. D;

A. Prokopenko;

Center for Military and Strategic Studies of the National Defence University of Ukraine named after Ivan Chernyhovsky, Kyiv

Analysis of experience of leading countries of the world in relation to forming and drawing on skilled reserve in the armed forces

Resume. In the article experience of armies of leading countries of the world is generalized on creation of skilled reserve and the analysis of world tendencies is carried out in relation to automation of processes of skilled management.

Keywords: skilled reserve, completing of the armed forces, principles of forming of the armed forces, CASS of management by a personnel. 